Pena Justisia: Media Komunikasi dan Kajian Hukum
Vol. 17 No. 1, 2017, 37-46
Artikel Hasil Penelitian

\title{
Peran Desa Sebagai Basis Migrasi Aman Dalam Perlindungan Tenaga Kerja Indonesia
}

\author{
Riris Ardhanariswari, Kadar Pamuji, Oktafiani Catur P. \\ Fakultas Hukum Universitas Jendral Soedirman, Indonesia
}

Artikel Diterima:

27 November 2017

Artikel Disetujui:

8 Desember 2017

Artikel Diterbitkan:

15 Desember 2017

Korespondensi Penulis:

ririsardhana@gmail.com

\begin{abstract}
The lack of knowledge possessed by Indonesian labor abroad gives rise to some vulnerability. An urgent problem to solve is the formulation of village regulations on the protection of the Pamijen Village workforce in order for Indonesian workers from Pamijen Village to be protected for safe migration and to ensure that abandoned families can educate abandoned children well. This research uses a qualitative approach because it has advantages in constructing social reality, cultural meaning, focusing on interactive processes and events. The authors discussed with Pamijen Village Government to get inputs related to improving the capacity of the village apparatus through training on the formulation of Village Regulations on the Protection of Indonesian Workers and then conducting public hearing activities through focus group discussions. The results of the research conducted in Pamijen Village, Sokaraja Sub-district resulted in an agreement to draft the Pamijen Village Rule of Regulation on the Protection of Prospective Indonesian Workers/Indonesian Migrant Workers and Their Families
\end{abstract}

Keywords: Village, Protection, Indonesian Worker

\section{Abstrak}

Masalah yang mendesak untuk diselesaikan adalah penyusunan peraturan desa tentang perlindungan tenaga kerja Desa Pamijen agar tenaga kerja Indonesia asal Desa Pamijen mendapatkan perlindungan untuk melakukan migrasi aman dan memastikan bahwa keluarga yang ditinggalkan bisa mendidik anak yang ditinggalkan dengan baik. Penelitian ini menggunakan pendekatan kualitatif karena memiliki kelebihan dalam mengkonstruksikan realitas sosial, makna budaya, mempunyai fokus pada proses interaktif maupun peristiwa. Penulis melakukan diskusi dengan Pemerintah Desa Pamijen untuk mendapatkan masukan-masukan berkaitan dengan peningkatan kapasitas perangkat desa melalui pelatihan penyusunan Peraturan Desa tentang Perlindungan Tenaga Kerja Indonesia kemudian melakukan kegiatan public hearing melalui focus group discussion. Hasil penelitian yang dilakukan di Desa Pamijen Kecamatan Sokaraja menghasilkan sebuah kesepakatan untuk menyusun Rancangan Peraturan Desa Pamijen tentang Perlindungan Calon Tenaga Kerja Indonesia/ Tenaga Kerja Indonesia dan Keluarganya.

Kata kunci: Desa, Perlindungan, Tenaga Kerja Indonesia 


\section{PENDAHULUAN}

Kabupaten Banyumas merupakan salah satu kantong pengirim tenaga kerja ke luar negeri yang menduduki peringkat keenam di Jawa Tengah. Dorongan warga Banyumas untuk bekerja di luar negeri mayoritas adalah karena faktor ekonomi terutama minimnya lapangan kerja di daerah yang bisa diserap oleh tenaga kerja unskill dan jeratan hutang. Minimnya pengetahuan yang dimiliki oleh para tenaga kerja Indonesia di luar negeri menimbulkan beberapa kerawanan atau kerentanan. Kerentanan tersebut dikarenakan beberapa hal, yakni latar belakang pendidikan, status, hingga kondisi ekonomi. Ada fakta yang tidak bisa dihindari selama ini bahwa sebagian besar buruh migran Indonesia adalah perempuan dan bekerja di sektor domestik. Hingga tahun 2013, tercatat bahwa buruh migran perempuan yang berdokumen resmi dan tercatat lebih banyak dibanding buruh migran laki-laki. Tahun $2010 \mathrm{mi}-$ salnya dari total BMI terdiri dari 78\% perempuan dan 22\% laki-laki. Kuat dugaan apabila hitungan tersebut juga menyertakan BMI yang tidak berdokumen resmi, maka akan semakin banyak buruh migran perempuan dibandingkan dengan laki-laki.

Kerentanan berikutnya adalah rendahnya rata-rata pendidikan terakhir yang diikuti BMI. Tingkat pendidikan rata-rata pekerja migran Indonesia ada pada tingkat SD dan SMP. Sebuah bekal yang masih prematur ketika harus dihadapkan pada keras dan asingnya lingkungan kerja di luar negeri. Rendahnya pendidikan ini juga yang berimplikasi pada kerentanan BMI ketika berinteraksi dengan bahasa dan budaya yang berbeda. Belum lagi tingkat adaptasi dengan pola kerja yang dihadapi di luar negeri. Ini kemudian yang juga mengakibatkan tingginya kasus penipuan dan perdagangan manusia. Sektor domestik memang menempati urutan tertinggi jenis pekerjaan BMI karena sektor inilah yang paling mudah diakses dari segi pendidikan dan menengah dan tidak membutuhkan ijazah keahlian lain. ${ }^{1}$

Dorongan warga Banyumas untuk melakukan migrasi ke luar negeri yang semakin banyak secara teoritis bisa dijelaskan sebagai berikut; pertama, aliran neo klasik yang melihat bahwa migrasi terjadi karena kelebihan tenaga kerja di suatu wilayah dan kebutuhan akan tenaga kerja di wilayah lainnya. Akibatnya, akan terjadi aliran tenaga kerja dari wilayah yang mengalami kelebihan tenaga kerja ke wilayah yang membutuhkan tenaga kerja. Kedua; aliran stukturalis yang memandang bahwa migrasi tenaga kerja internasional terjadi karena ketidakseimbangan pembangunan di dunia maju dan di dunia ketiga.

Dalam upaya mengakumulasi kapital, dunia maju memerlukan tenaga buruh murah yang dapat menjamin kelanggengan produksi dan reproduksi sosial warga negaranya. Untuk dapat mempertahankan produktivitas kerjanya dan juga pertumbuhan ekonomi negara-negara tersebut, keluarga-keluarga di negara-negara maju membutuhkan seseorang yang mampu menangani urusan domestik mereka mereka dengan tingkat upah yang relatif lebih rendah dibanding menggunakan tenaga kerja lokal. Oleh karena itu, proses migrasi menjadi siklus panjang.

Bagi negara-negara berkembang dan ketiga, ketika dorongan warga negaranya untuk melakukan migrasi meningkat terus-menerus maka menjadi masalah dan pekerjaan rumah sendiri bagi pemerintah baik pemerintah di level nasional maupun di level lokal. Pasalnya problem migrasi bisa menimpa buruh migran maupun keluarganya. Problem yang menimpa buruh migran di luar negeri antara lain perlakuan yang tidak manusiawi dari majikan, gaji yang rendah dan ada beberapa kasus gaji buruh migran yang tidak dibayarkan oleh majikan. Kasus yang ditemukan oleh Garda Buruh Migran Indonesia diantaranya majikan melakukan kontrak dengan perusahaan jasa TKI se-

Bara Berlian, "Perlindungan Sosial (Social Protection) untuk Buruh Migran Indonesia", Dikutip dari Laman: https:// www.academia.edu/10628398/Perlindungan_So sial_Social_Protection_untuk_Buruh_Migran_Indonesia 
39 Pena Justisia: Media Komunikasi dan Kajian Hukum Vol. 17, No. 2, 2017

besar 45 ribu riyal Arab Saudi per tahun atau setara dengan Rp 171 juta. Namun perusahaan memberikan gaji kepada pembantu hanya 1.500 riyal Arab Saudi per bulan untuk membayar gaji atau setara dengan Rp 5,7 juta per bulan (Rp 68 juta per tahun). ${ }^{2}$ Kasus lain adalah kasus asusila yang banyak menimpa tenaga kerja Indonesia (TKI) di Arab Saudi. Aturan syariat ketat yang dijalankan pemerintahan Kerajaan Arab Saudi membuat cukup banyak TKI harus berurusan dengan polisi syariah setempat. Rata-rata 109 kasus asusila dalam satu tahun. Bentuk kasus asusila bisa bermacam-macam sesuai dengan norma yang berlaku di masyarakat, misalnya berduaan dengan lawan jenis yang bukan muhrim bisa dianggap sebagai bentuk pelanggaran kesusilaan dan harus diproses secara hukum. Hal ini yang terkadang tidak dipahami oleh tenaga kerja asal Indonesia yang mungkin terbiasa dengan situasi yang berbeda di daerah asalnya. Kasus lain yang cukup menonjol yang sering menjerat tenaga kerja asal Indonesia di Arab Saudi adalah kasus perzinaan dengan rata-rata 65 kasus per tahun serta kasus kriminal seperti pencurian, penipuan, pemalsuan dan kasus-kasus lainnya juga cukup banyak dilakukan oleh tenaga kerja Indonesia dengan jumlah 33 kasus per tahun hingga kasus perkosaan oleh majikan dan pembunuhan. ${ }^{3}$

Kasus yang paling banyak tidak diungkap dan di ekspos oleh media adalah kasus keluarga buruh migran diantaranya anak-anak yang ditinggalkan oleh orang tua bekerja di luar negeri cenderung menjadi anak yang nakal karena kehilangan kasih sayang orang tua terutama ibu. Hasil penelitian yang dilakukan oleh Riris, dkk tentang Pembentukan Model Perlindungan Anak Buruh Migran di Kabupaten Banyumas tahun 2011 menemukan permasalahan tentang anak buruh migran yaitu

2 "Aktivis Dukung Kebijakan Setop PRT Ke Timur Tengah", Dikutip dari Laman: http://www.republi-ka.co.id/berita/ nasional/umum/16/05/25/o7q7v5365-aktivis-dukungkebijakan-setop-prt-ke-timur-tengah

3 "TKI di Saudi Saling Sering Terkena Masalah dalam Kasus Asusila", Dikutip dari Laman: http://www.tribunnews.com/nasional/2013/12/12/tki-di-saudi-palingsering-terkena-masalah-dalam-kasus-asusila belum ada perhatian dari pemerintah tentang anak buruh migran. Padahal anak memiliki hak anak yang dijamin dalam Undang-Undang Nomor 23 Tahun 2002 tentang Perlindungan Anak. Sehingga menurut Riris, dkk diperlukan sebuah sistem yang memungkinkan kerjasama antara pemerintah, masyarakat, keluarga dan orang tua pengasuh (children left-behind). ${ }^{4}$

Beberapa kasus yang menimpa buruh migran dan keluarganya tersebut mendorong pemerintah untuk membuat undang-undang perlindungan tenaga kerja Indonesia Undang-Undang Nomor 39 Tahun 2004 tentang Penempatan dan Perlindungan Tenaga Kerja Indonesia di Luar Negeri. Namun, undang-undang ini dianggap sangat lemah karena hanya mengatur tentang buruh migran saja dan tidak mengatur tentang keluarga buruh migran. Sementara yang terjadi di lapangan selama ini banyak kasus yang menimpa buruh migran Indonesia diawali karena ketidaktahuan calon dan keluarganya tentang migrasi aman, bahkan permainan para calo tenaga kerja seringkali memainkan ijin dari keluarga sebagai salah satu syarat untuk berangkat bekerja ke luar negeri. Pemerintah desa sebagai level terendah ternyata juga memberi kontribusi terjadinya migrasi yang tidak aman karena ketidahtahuan aparat desa tentang migrasi aman.

Kabupaten Banyumas dalam upayanya melindungi tenaga kerja Indonesia asal Banyumas telah membuat Peraturan Daerah Nomor 2 Tahun 2015 tentang Perlindungan Tenaga Kerja Indonesia Kabupaten Banyumas. Dalam perda ini diatur tentang tenaga kerja Indonesia asal Banyumas untuk memberikan perlindungan bagi tenaga kerja asal Banyumas yang akan bekerja di luar negeri beserta keluarganya. Dengan adanya perda tersebut, pemerintah desa harus mengadopsi di

4 Riris Ardhanariswari dkk, 2011, Pembentukan Model Perlindungan Anak Buruh Migran di Kabupaten Banyumas. 
level desa melalui peraturan desa sebagai payung hukum pemerintah desa untuk melindungi warga desanya agar bisa melakukan migrasi dengan aman.

\section{PERMASALAHAN}

Berdasarkan uraian pada latar belakang masalah di atas, permasalahan yang dikaji dalam artikel ini adalah: Pertama, bagaimanakah cara merealisasikan pembentukan Peraturan Desa dengan keterbatasan pengetahuan tentang penyusunan peraturan desa tentang perlindungan tenaga kerja Indonesia; Kedua, bagaimanakah bentuk pendampingan dalam menyusun untuk peraturan desa tersebut.

\section{METODE PENELITIAN}

Penelitian ini menggunakan pendekatan kualitatif karena memiliki kelebihan dalam mengkonstruksikan realitas sosial, makna budaya, mempunyai fokus pada proses interaktif maupun peristiwa. ${ }^{5}$ Peneliti bermaksud menggali dan menemukan permasalahan dan hal yang menjadi penyebab timbulnya masalah. Langkah yang akan dilakukan dalam penelitian ini, dengan menganalisa/ mengkaji bekerjanya hukum di masyarakat (law in action), serta aspek-aspek sosial yang mempengaruhi bekerjanya hukum dalam masyarakat. Penelitian dilakukan di Desa Pamijen, Kecamatan Sokaraja, Kabupaten Banyumas. Penelitian ini menggunakan teknik pengumpulan data dengan kombinasi wawancara. FGD, studi dokumen, dan observasi. ${ }^{6}$ Pengolahan dan analisis data penelitian ini yaitu dari David M Silbergh. ${ }^{7}$ Pengembangan kategori yang analitik dan coding data merupakan prasyarat bagi analisis. Pengelompokan data dilakukan secara logis. Pengembangan kategori atau koding data memperhatikan; Menjamin kategori analitik konsisten dengan tujuan dan sasaran penelitian, sehingga kesimpulannya valid; Keseimbangan untuk menjaga pengkategorian

5 Lawrence Newman, 1994, Social Research Methods: Qualitative and Quantitative Approachs, Boston: Allyn and Bacon, hlm. 14.

6 Keith Punch, 2006, Developing Effective Research Proposal, London: Sage Publication, hlm. 52. yang terlalu sedikit dan yang terlalu banyak; Dalam tahapan kategori yang analitik, peneliti melakukan pengkajian keselarasan dengan tujuan dan sasaran studi; coding data dilakukan secara kritis.

Pengolahan dan analisis data dilakukan pada saat pengumpulan data secara berkelanjutan. Diawali dengan proses klarifikasi data agar tercapai konsistensi, dilanjutkan dengan langkah abstraksi teoritis terhadap informasi dan fakta, yang menghasilkan pernyataan-pernyataan yang mendasar. Dengan cara melakukan komparasi temuan penelitian dan pendalaman makna, akan diperoleh suatu analisis data yang terus-menerus secara simultan sepanjang proses penelitian.

\section{PEMBAHASAN}

\section{Pemerintahan Desa}

Undang-Undang Nomor 6 Tahun 2014 tentang Desa lahir berdasarkan amanat Pasal 18B ayat (2) UUD 1945, yang menyatakan "Negara mengakui dan menghormati kesatuan-kesatuan masyarakat hukum adat beserta hak-hak tradisionalnya sepanjang masih hidup dan sesuai dengan perkembangan masyarakat dan prinsip Negara Kesatuan Republik Indonesia, yang diatur dalam undang-undang".

Pasal 18B ayat (2) UUD 1945 ditegaskan pula adanya kesatuan masyarakat hukum adat yang diakui dan dihormati keberadaannya oleh negara. Adanya kesatuan masyarakat hukum adat itu terbentuk berdasarkan 3 (tiga) prinsip dasar, yaitu genealogis, teritorial, dan/ atau gabungan antara prinsip genealogis dan prinsip teritorial, yang diatur dalam Undang-Undang Nomor 6 Tahun 2014 adalah kesatuan masyarakat hukum adat yang merupakan gabungan antara genealogis dan teritorial.

Undang-undang Nomor 6 Tahun 2014 tentang Desa lahir dalam rangka memperbaiki (problem solving) problematika-problematika hukum

7 Silbergh merujuk pada analisis data Creswell (1994) dan Straus \& Corbin (1990), dalam David M Silbergh, Doing Dissertations in Politics: A Student Guide, London: Routledge, 2001, hlm. 173-175. 
pemerintahan desa dalam tataran konseptualisasi yuridis, memperbaiki problematika hukum pemerintahan desa yang ada atau justru dengan adanya perubahan pengaturan tata pemerintahan desa akan menambah problematika yang ada karena perubahan terhadap tata pemerintahan desa pasti berdampak pada perubahan dalam kedudukan, kewenangan, tugas, fungsi organisasi, keuangan dan sebagainya. Dampaknya, tidak hanya positif bagi perkembangan dan pembangunan di tingkat desa, tetapi juga memunculkan konflik dalam hubungannya dengan kedudukan pemerintahan desa dengan pemerintah di atasnya.

Undang-Undang Nomor 6 Tahun 2014 tentang Desa ini disahkan, pemerintah desa sebagai birokrasi perlu mentrasformasi diri menjadi, : 1) birokrasi pemerintahan umum, yaitu rangkaian organisasi pemerintahan yang menjalankan tugas-tugas pemerintahan umum termasuk memelihara ketertiban dan keamanan, 2) birokrasi pembangunan yang memiliki fungsi pokoknya yaitu fungsi pembangunan atau fungsi adaptasi; karena hal yang melatarbelakangi terbitnya undang-undang ini adalah masih adanya ketimpangan pembangunan di desa dan 3) birokrasi pelayanan, yaitu unit organisasi pemerintahan yang pada hakikatnya merupakan bagian atau berhubungan dengan masyarakat. Fungsi utamanya adalah pelayanan (service) langsung kepada masyarakat. Pelayanan di sini bisa dimaknai sebagai mengakomodasi langsung aspirasi masyarakat desa.

Untuk menjawab berbagai tantangan yang muncul dari Undang-undang Nomor 6 Tahun 2014 tentang Desa ini, maka sebagai awalan perlu sosialisasi Undang-undang Nomor 6 Tahun 2014 tentang Desa dan pendidikan politik secara massif dan holistik di seluruh desa dengan pendekatan dan metodologi yang tepat. Pendidikan politik ini diselenggarakan dalam kepentingan intervensi sosial dalam membangun kesadaran masyarakat, terutama dalam kesadaran kritis sehingga ke depan partisipasi masyarakat dalam pemilihan kepala desa adalah partispasi yang kririts. Karena partisipasi merupakan indikator penting untuk mengukur perilaku keberhasilan masyarakat desa dan kepentingan dalam pemilihan kepala desa.

Undang-undang Nomor 6 Tahun 2014 tentang Desa ini bisa memajukan adat istiadat dan budaya masyarakat desa, membangun sistem pemerintahan lebih efektif dalam kerangka pelayanan masyarakat, memajukan perekonomian masyarakat desa serta memupus kesenjangan pembangunan nasional. Untuk mengoptimalkan peluang tersebut, maka strategi yang perlu diperjuangkan adalah mendidik rakyat desa, supaya memiliki kemampuan untuk mengorganisasikan dirinya (self help) dan memobilisasi semua sumber daya yang ada di desa. Sebagai pengembangan masyarakat yang menjadi upaya terorganisir yang dilakukan guna meningkatkan kondisi masyarakat, terutama melalui usaha kooperatif dan mengembangkan kemandirian pedesaan. Penguatan kapasitas masyarakat desa dengan cara mendorong mereka untuk terlibat langsung dalam mengontrol dan mengawasi pemerintah desa, menjadi kata kunci untuk mencapai masyarakat desa yang makmur, adil dan demokratis. Tanpa itu, masyarakat desa tetap terbelit dalam persoalan jeratan kemiskinan.

Undang-undang Nomor 6 Tahun 2014 tentang Desa maka, pembangunan desa yang dilaksanakan berdasarkan peraturan desa untuk memenuhi aspek keberlakuan hukum dan dapat dilaksanakan sesuai tujuan pembentukannya termasuk juga meningkatkan peran masyarakat terhadap pembangunan desanya. Dalam rangka hal ini, peraturan desa yang partisipatif dapat dilakukan dengan jalan sebagai berikut: a) identifikasi persoalan di masyarakat; b) menerima masukan masyarakat/keterlibatan masyarakat dalam proses penyusunan regulasi desa; c) membuat topik regulasi desa; d) membuat draft atau kerangka umum regulasi desa; e) konsultasi publik; f) regulasi desa dengan kearifan lokal; g) revisi dari draft Peraturan Desa hasil konsultasi publik; h) penetapan regulasi desa bahwa kepala desa dengan BPD sebab menurut Undang-undang Nomor 6 Tahun 2014 tentang Desa, penetapan regulasi desa menjadi sebuah kesepakatan antara Kepala 
Desa dengan BPD); dan i) implementasi regulasi desa.

Bagian paling penting untuk mendukung otonomi desa mengenai partisipasi masyarakat dalam pembangunan adalah pada tahap identifikasi masalah. Di bidang kesejahteraan sosial, masyarakat melalui forum-forum maupun Pokja (kelompok kerja) dapat menyampaikan aspirasi berupa program pembangunan kesejahteraan sosial desa. Hal ini, bukan saja nantinya aneka masalah sosial dapat terdeteksi dan menjadi bagian dari prioritas pembangunan desa tetapi disisi lain juga tergeraknya masyarakat untuk peduli terhadap sesama warganya yang mengalami masalah sosial. Pada tahap selanjutnya Desa akan mampu menangani permasalahan sosial daerahnya secara mandiri. Undang-undang Nomor 6 Tahun 2014 tentang Desa bukan saja hanya akan meningkatkan peran serta masyarakat untuk terlibat dalam pembangunan desa tetapi Undang-undang Nomor 6 Tahun 2014 tentang Desa juga sekaligus momentum untuk meningkatkan kemandirian desa dalam menangani permasalahan sosial di daerahnya.

Pemerintahan Desa adalah penyelenggaraan urusan pemerintahan dan kepentingan masyarakat setempat dalam sistem pemerintahan Negara Kesatuan Republik Indonesia. Desa memiliki kedudukan yang sangat penting dan strategis dalam rangka pembangunan nasional dan terselenggaranya struktur pemerintahan negara Indonesia. Hal tersebut membuat desa merupakan suatu institusi otonom dengan tradisi, adat-istiadat dan hukumnya sendiri serta relatif mandiri. Berdasarkan hal ini, maka desa harus dipahami sebagai kesatuan masyarakat hukum yang memiliki hak dan kekuasaan dalam mengatur dan mengurus kepentingan masyarakatnya untuk mencapai kesejahteraan. Hak untuk mengatur dan mengurus kepentingan masyarakat inilah yang disebut otonomi desa.

$8 \quad$ Yuliandri, 2009, Asas-asas Pembentukan Peraturan Perundang-undangan yang baik, Rajawali Pers, Jakarta, hlm. 24.

\section{Peraturan Desa}

Saat ini desa diberikan kewenangan yang lebih luas dalam mengatur dan mengurus kepentingan masyarakat. Dalam rangka ini, sejumlah Peraturan Desa harus dibuat untuk mengefektifkan implementasi kewenangan tersebut. Pentingnya Peraturan desa ini juga bertujuan untuk mempercepat terwujudnya kesejahteraan masyarakat melalui peningkatan, pelayanan, pemberdayaan, dan peran serta masyarakat, serta peningkatan daya saing daerah dengan memperhatikan prinsip demokrasi, pemerataan, keadilan, keistimewaan dan kekhususan suatu daerah dalam sistem Negara Kesatuan Republik Indonesia, akan tetapi peraturan desa yang dibuat hendaknya mempertimbangkan keutuhan dan kemampuan masyarakat untuk melaksanakannya. Untuk itu, maka proses penyusunan peraturan desa harus memperhatikan asprirasi masyarakat.

Peraturan Desa merupakan peraturan yang bersipat lokal. peraturan desa dibentuk berdasarkan asas-asas peraturan perundang-undangan. A. Hamid S. Attamimi berpendapat, bahwa asas pembentukan peraturan perundang-undangan yang patut khususnya dalam ranah keindonesiaan, terdiri atas: Cita Hukum Indonesia, Asas Negara Berdasarkan Hukum, Asas Pemerintahan Berdasarkan Konstitusi dan asas-asas lainnya. ${ }^{8}$ Selanjutnya menurut Maria Farida Indrati menegaskan pembentukan peraturan perundang-undangan, disamping menganut asas-asas pembentukan perundang-undangan yang baik, juga berlandasakan juga pada asas-asas hukum umum, yang terdiri atas asas hukum umum negara berdasarkan atas hukum, asas hukum umum pemerintahan berasarkan sistem konstitusi, asas hukum negara berdasarkan kedaulatan rakyat. ${ }^{9}$

Berdasarkan Undang-Undang No. 12 Tahun 2011 tentang Pembentukan Peraturan Perundang-Undangan, Peraturan Desa adalah peraturan perundang-undangan yang dibuat oleh Badan Perwakilan Desa atau dengan nama lainnya bersama

9 Maria Farida Indrati, 1998, Ilmu Perundang-undangan, Kanisius, Yogyakarta, hlm.196-197. 
43 Pena Justisia: Media Komunikasi dan Kajian Hukum

Vol. 17, No. 2, 2017

dengan Kepala Desa atau nama lainnya. Tata cara penyusunan undang-undang sampai dengan perda kabupaten/ kota diatur dalam Undang- Undang Nomor 12 Tahun 2011, sedangkan ketentuan mengenai tata cara pembuatan peraturan desa di delegasikan oleh Undang-Undang Nomor 12 Tahun 2011 untuk diatur oleh Peraturan daerah Kabupaten/ Kota yang bersangkutan. Pendelegasian mengatur tata cara pembuatan peraturan desa ini rupa-rupanya dimaksudkan untuk mengakomodasi keanekaragaman desa di masing-masing Kabupaten atau Kota

\section{Partisipasi Masyarakat}

Partisipasi secara harfiah dimaknai sebagai pengambilan bagian atau pengikut-sertaan. Menurut Adams, partisipasi sangat penting bagi pembangunan diri dan kemandirian warga negara. Melalui partisipasi, individu menjadi warga publik, dan mampu membedakan persoalan pribadi dengan persoalan masyarakat. Tanpa partisipasi, nyaris semua orang akan ditelan oleh kepentingan pribadi dan pemuasan kebutuhan pribadi mereka yang berkuasa. Partisipasi politik oleh Budiarjo secara umum diartikan sebagai kegiatan seseorang atau sekelompok orang untuk ikut serta secara aktif dalam kehidupan politik yaitu dengan jalan memilih pimpinan negara secara langsung atau tidak langsung mempengaruhi kebijakan pemerintah (public policy). ${ }^{10}$

Tingkat partisipasi politik masyarakat cenderung berlainan atas dasar status ekonomi. Umumnya mereka yang memiliki tingkat pendidikan lebih tinggi, cenderung lebih berpartisipasi daripada yang miskin, tak berpendidikan dan memiliki kualitas pekerjaan rendah. Logika politik yang digunakan dalam hal ini bahwa pembangunan akan menghasilkan banyak orang yang berpendidikan, berpenghasilan relatif tinggi dan status pekerjaan yang tinggi sehingga partisipasi politik masyarakat cenderung meningkat. Idealnya, setiap keputusan politik yang diambil oleh supra struktur politik dilakukan melalui konvensi dan dikaitkan kembali dengan masyarakat. Dalam konteks Indonesia, pertumbuhan ekonomi yang terjadi telah mendatangkan aspirasi-aspirasi dan tuntutan-tuntutan baru yang senantiasa menuntut strategi pembangunan baru untuk mengakomodasinya.

Partisipasi masyarakat dalam proses pembentukan peraturan perundang- undangan, diatur pada Pasal 96 Undang-undang Nomor 12 Tahun 2011, ayat (1) dan (2) sebagai berikut:

(1) Masyarakat berhak memberikan masukan secara lisan dan/ atau tertulis dalam pembentukan peraturan perundangan-undangan.

(2) Masukan secara lisan dan/ atau tertulis sebagaimana dimaksud pada ayat (1) dapat dilakukan melalui (a) rapat dengan pendapat umum, (b) kunjungan kerja, (c)sosialisasi dan/ atau (d) seminar, lokakarya dan/ atau diskusi.

Menurut Diana Conyer, bahwa pentingnya partisipasi adalah sebagai berikut Pertama, partisipasi masyarakat merupakan suatu alat guna memperoleh informasi mengenai kondisi, kebutuhan, dan sikap masyarakat setempat, yang tanpa kehadirannya program pembangunan serta proyek-proyek akan gagal. kedua, bahwa masyarakat akan lebih mempercayai proyek atau program pembangunan jika merasa dilibatkan dalam proses persiapan dan perencanaannya, karena mereka akan lebih mengetahui seluk-beluk proyek tersebut dan akan mempunyai rasa memiliki terhadap proyek tersebut; ketiga, bahwa merupakan suatu hak demokrasi bila masyarakat dilibatkan dalam pembangunan masyarakat mereka sendiri".

\section{Peran Desa Sebagai Basis Migrasi Aman Dalam Perlindungan Tenaga Kerja Indonesia}

Masalah partisipasi memang menjadi masalah di masyarakat desa, karena setiap orang punya aktivitas sendiri-sendiri menjadi alasan pembenar untuk tidak mau aktif. Rumus pembang-

10 Miriam Budiarjo, 1982, Partisipasi dan Partai Politik, Gramedia, Jakarta, hlm. 1. 
kitan partisipasi adalah ada sambung rasa atau tidak. Jika ada sambung rasa maka sejalan dengan perkembangan partisipasi masyarakat. Jadi, masalah sambung rasa atau penciptaan chemistry itu sangatlah penting dalam menumbuhkan partisipasi dari masyarakat. Partisipasi berpengaruh agar efektif harus ada chemistry.

Peraturan desa ini diharapkan nantinya dapat menjangkau masalah TKW seperti yang ditanyakan tadi sebenarnya ada jenjang-jenjang peraturan yang ada di atas peraturan desa yang dapat menjangkau kasus tersebut. Karena jangkauan dan wewenangnya sudah berbeda dengan hal-hal yang ada di peraturan desa. Mengenai bisa tidak mengurangi atau menambah muatan isi dari sebuah peraturan desa sebenarnya bisa jika bentuknya masih berupa rancangan atau sebelum peraturan desa disahkan. Bisa juga diadakan sebuah amandemen jika peraturan desa itu sudah disahkan namun untuk melaksanakan sebuah amandemen sedikit rumit. Lebih baik merubah saat sebelum disahkan saat masih berbentuk rancangan. Peraturan desa ini bisa mengejewantahkan pikiran-pikiran masyarakat desa. Menyumbang segala saran dan kebutuhan-kebutuhan yang memang benar-benar diperlukan oleh masyarakat desa. Jadi,peraturan desa yang dibuat tidak mubadzir.

Desa mengalami beberapa konsep terkait dengan perubahan peraturan perundang-undangan. Perubahan ini terkait dengan kewenangan desa, yang dituntut adalah aspek kemandirian dari desa yaitu kemandirian untuk mengatur sehingga substansi desa sebagai pelayan, agen pembangunan dapat tercakup. Fenomena TKI baru bisa menyentuh desa ketika desa sudah memiliki produk hukum, sebelum desa punya payung hukum maka penanganan TKI/ CTKI akan menjadi bias. Perdes ini dapat berjalan efektif jika ada keterpaduan antara masyarakat, calon tenaga kerja, pemerintah desa, dan stakeholder yang ada harus menjadi satu nafas dan satu keinginan.
Berbagai persoalan yang muncul adalah agen (calo), oknum yang mengatasnakamakan agen PPTKIS tapi tidak memiliki lisensi dan keahlian, maka harus dijelaskan kepada masyarakat bahwa agen harus memiliki lisensi. Persoalan kedua adalah calon TKI, CTKI kadang-kadang tidak terbuka, sebagai contoh penandatanganan surat izin karena terkadang ada pemalsuan. Maka diharapkan kepada Kepala Desa dibuat peraturan teknis bahwa dalam pembuatan surat izin maka suami/ orang tuanya harus hadir di hadapan kepala desa. Ketiga ketika TKI sudah ada di negara tujuan terkadang terjadi putus hubungan dengan pemerintah desa. Keempat yaitu adanya pemaksaan kehendak sehingga ada yang memanipulasi usia dan pendidikan, sehingga dengan data yang tidak sinkron dengan desa menjadi persoalan. Produk hukum apapun levelnya memang ada pro dan kontra, maka diharapkan kepada masyarakat harus ada sanksi ketika masyarakat tidak memenuhi kewajiban. Kita harus menyadari bahwa pemerintahan desa harus berjalan bersama, sehingga harus ada kerjasama antara semua elemen. Sehingga harus ada kewajiban dari masing-masing elemen, bahwa masyarakat harus bekerjasama dengan pemerintah desa. Perdes adalah produk hukum tertinggi di desa, maka diharapkan untuk disebarluaskan, melembaga, dan memberikan manfaat bagi Perlindungan Calon Tenaga Kerja/ Tenaga Kerja Indonesia dan Anggota Keluarganya. ${ }^{11}$

Rancangan Perdes tentang Perlindungan CTKI/ TKI dan Keluarganya ini didasari pemikiran filosofis bahwa setiap warga berhak atas pekerjaan yang layak bagi kemanusiaan dan Pemerintah Desa mempunyai tanggung jawab memberikan pelayanan, jaminan dan perlindungan terhadap Calon Tenaga Kerja Indonesia/ Tenaga Kerja Indonesia dan keluarganya. Kabupaten Banyumas sudah memiliki Peraturan Daerah Kabupaten Banyumas Nomor 2 Tahun 2015 tentang Perlindungan Tenaga Kerja Indonesia Kabupaten Ba-

\footnotetext{
11 Paparan Camat Sokaraja, Drs. Purjito, disampaikan tanggal pada tanggal 13 Agustus 2017.
} 
nyumas, dalam Pasal 44 mengatur mengenai masyarakat berperan dalam perlindungan TKI. Pemerintah Desa memberikan perlindungan terhadap TKI berperan melakukan pendataan, melakukan penyuluhan dan melakukan koordinasi.

Perlindungan kepada CTKI/ TKI dan anggota keluarganya berasaskan asas persamaan/ nondiskriminasi, asas kesetaraan dan keadilan gender, asas akuntabilitas, asas manfaat, asas anti perdagangan manusia, dan asas partisipasi. Perlindungan CTKI/ TKI dan anggota keluarganya bertujuan untuk meningkatkan kesadaran, kepedulian dan tanggung jawab pemerintah desa, dunia usaha dan masyarakat, untuk mewujudkan rasa aman, meningkatkan kesejahteraan, kualitas hidup TKI dan keluarganya serta terjaminnya pemenuhan hak-haknya baik prapenempatan, masa penempatan sampai dengan purna penempatan. Ruang lingkup peraturan desa ini adalah: a) Pendataan; b) Pelayanan Dokumen; c) Pelayanan Informasi; d) Pengaduan; e) Penyuluhan; f) Koordinasi; g) Pendidikan Manajemen Pengelolaan Pendapatan; h) Pusat Pelayanan Terpadu Desa Peduli Calon TKI/TKI dan Keluarganya; h) Hak dan Kewajiban; i) Pembiayaan; j) Pembinaan dan Pengawasan; k) Ketentuan Penutup.

Langkah selanjutnya dari kegiatan penelitian ini maka diharapkan pemerintah desa Pamijen memasukkan dam perencanaan untuk tahun 2018 untuk pembuatan peraturan desa tentang perlindungan calon TKI/ TKI dan keluarganya. Rancangan Peraturan Desa yang telah disusun, wajib dikonsultasikan kepada masyarakat desa dan dapat dikonsultasikan kepada camat untuk mendapatkan masukan. Selain itu masukan dari masyarakat masih dimungkinkan, karena yang dilakukan oleh peneliti masih memungkinkan untuk diberi masukkan.

Alur pembentukan peraturan desa, BPD mengundang Kepala Desa untuk membahas dan menyepakati rancangan Peraturan Desa. Dalam hal terdapat rancangan Peraturan Desa prakarsa
Pemerintah Desa dan usulan BPD mengenai hal yang sama untuk dibahas dalam waktu pembahasan yang sama, maka didahulukan rancangan Peraturan Desa usulan BPD sedangkan Rancangan Peraturan Desa usulan Kepala Desa digunakan sebagai bahan untuk dipersandingkan. Rancangan peraturan Desa yang telah disepakati bersama disampaikan oleh pimpinan Badan Permusyawaratan Desa kepada kepala Desa untuk ditetapkan menjadi peraturan Desa paling lambat 7 (tujuh) hari terhitung sejak tanggal kesepakatan. Rancangan peraturan Desa sebagaimana dimaksud pada ayat (1) wajib ditetapkan oleh kepala Desa dengan membubuhkan tanda tangan paling lambat 15 (lima belas) Hari terhitung sejak diterimanya rancangan peraturan Desa dari pimpinan Badan Permusyawaratan Desa. Rancangan Peraturan Desa yang telah dibubuhi tanda tangan disampaikan kepada Sekretaris Desa untuk diundangkan. Dalam hal Kepala Desa tidak menandatangani Rancangan Peraturan Desa sebagaimana dimaksud pada ayat (1), Rancangan Peraturan Desa tersebut wajib diundangkan dalam Lembaran Desa dan sah menjadi Peraturan Desa. Sekretaris Desa mengundangkan peraturan desa dalam lembaran desa. Peraturan Desa dinyatakan mulai berlaku dan mempunyai kekuatan hukum yang mengikat sejak diundangkan.

Penyebarluasan dilakukan oleh Pemerintah Desa dan BPD sejak penetapan rencana penyusunan rancangan Peraturan Desa, penyusunan Rancangan Peratuan Desa, pembahasan Rancangan Peraturan Desa, hingga Pengundangan Peraturan Desa. Penyebarluasan dilakukan untuk memberikan informasi dan/ atau memperoleh masukan masyarakat dan para pemangku kepentingan. ${ }^{12}$ Berdasarkan ketentuan Permendagri Nomor 111 Tahun 2014 maka tahapan untuk menjadi sebuah Perdes jika masih berupa rancangan/ draft maka masih dimungkinkan terjadinya perubahan dalam Raperdes tersebut.

\footnotetext{
12 Peraturan Menteri Dalam Negeri No. 111 Tahun 2014 tentang Pedoman Teknis Peraturan Di Desa.
} 


\section{PENUTUP}

\section{Simpulan}

Berdasarkan hasil penelitian dan pembahasan dapat diambil simpulan sebagai berikut: Pertama, hasil penelitian yang dilakukan di Desa Pamijen Kecamatan Sokaraja menghasilkan sebuah kesepakatan untuk menyusun Rancangan Peraturan Desa Pamijen tentang Perlindungan Calon Tenaga Kerja Indonesia/ Tenaga Kerja Indonesia dan Keluarganya dan tersusunnya Draft Rancangan Peraturan Desa Pamijen tentang Perlindungan Calon Tenaga Kerja Indonesia/ Tenaga Kerja Indonesia dan Keluarganya yang sudah dibahas secara mendalam dan mendapatkan masukkan dari masyarakat. Kedau, Raperdes ini diharapkan mampu mengatasi permasalahan yang dihadapi oleh masyarakat terutama Calon TKI/ TKI dan keluarganya serta untuk menjamin kepastian hukum.

\section{Saran}

Pertama, Pertemuan rutin yang dilakukan oleh pemerintah desa beserta warga masyarakat tetap harus dilanjutkan sebagai sarana untuk menyerap aspirasi masyarakat yang ada di Desa Pamijen. Kedua, Rancangan Peraturan Desa Pamijen tentang Perlindungan Calon Tenaga Kerja Indonesia/ Tenaga Kerja Indonesia dan Keluarganya yang sudah tersusun segera ditindaklanjuti oleh BPD dan Pemerintah Desa Pamijen untuk segera dibahas dan disahkan menjadi Peraturan Desa.

\section{DAFTAR PUSTAKA}

Budiarjo, Miriam. 1982. Partisipasi dan Partai Politik. Jakarta: Gramedia;

Indrati, Maria Farida. 1998. Ilmu Perundang-undangan. Yogyakarta: Kanisius;

Newman, Lawrence. 1994. Social Research Methods: Qualitative and Quantitative Approachs. Boston: Allyn and Bacon;

Riris Ardhanariswari dkk. 2011. Pembentukan Model Perlindungan Anak Buruh Migran di Kabupaten Banyumas;
Silbergh, David M. 2009. Doing Dissertations in Politics: A Student Guide. London: Routledge;

Yuliandri. 2009. Asas-asas Pembentukan Peraturan Perundang-undangan yang baik, Jakarta: Rajawali Pers;

Berlian, Bara. "Perlindungan Sosial (Social Protection) untuk Buruh Migran Indonesia", Dikutip dari Laman: https://www.academia.edu/10628398/Perlindungan_Sosial_So cial_Protection_untuk_Buruh_Migran_Indon esia

"Aktivis Dukung Kebijakan Setop PRT Ke Timur Tengah", Dikutip dari Laman: http:// www.republika.co.id/berita/nasional/umu m/16/05/25/o7q7v5365-aktivis-dukungkebijakan-setop-prt-ke-timur-tengah

"TKI di Saudi Saling Sering Terkena Masalah dalam Kasus Asusila", Dikutip dari Laman: http:// www.tribunnews.com/nasional/2013/12/1 2/tki-di-saudi-paling-sering-terkenamasalah-dalam-kasus-asusila 